\title{
3-Hydroxykynurenic acid: Physicochemical properties and fluorescence labeling
}

\author{
María S. Shmidt ${ }^{\mathrm{a}}$, María C. García Vior ${ }^{\mathrm{a}}$, Sergio D. Ezquerra Riega ${ }^{\mathrm{a}}$, Juan M. Lázaro-Martínez ${ }^{\mathrm{a}, \mathrm{b}}$, \\ María I. Abasolo $^{a}$, Ana Lazaro-Carrillo ${ }^{c}$, Andrea Tabero ${ }^{c}$, Angeles Villanueva ${ }^{c, d}$, \\ Albertina G. Moglioni ${ }^{\mathrm{a}, \mathrm{b}}$, María M. Blanco ${ }^{\mathrm{a}, *}$, Juan C. Stockert ${ }^{\mathrm{e}, \mathrm{f}, * *}$ \\ ${ }^{a}$ Universidad de Buenos Aires, Facultad de Farmacia y Bioquímica, Departamento de Química Orgánica, Junín 956 (C1113AAD), CABA, Argentina \\ ${ }^{\mathrm{b}}$ Universidad de Buenos Aires, Facultad de Farmacia y Bioquímica, IQUIMEFA-CONICET, Junín 956 (C1113AAD), CABA, Argentina \\ ${ }^{\mathrm{c}}$ Universidad Autónoma de Madrid, Facultad de Ciencias, Departamento de Biología, 28049, Madrid, Spain \\ ${ }^{\mathrm{d}}$ Instituto Madrileño de Estudios Avanzados en Nanociencia (IMDEA Nanociencia), Faraday 9, 28049, Madrid, Spain \\ ${ }^{\mathrm{e}}$ Universidad de Buenos Aires, Instituto de Oncología Ángel H. Roffo, Área Investigación, (C1417DTB), CABA, Argentina \\ ${ }^{\mathrm{f}}$ Universidad de Buenos Aires, Facultad de Ciencias Veterinarias, Instituto de Investigación y Tecnología en Reproducción Animal, (C1427CWO), CABA, Argentina
}

\section{A R T I C L E I N F O}

\section{Keywords:}

Fluorescent labeling

Quinolinones

Fluorophore

Biocompatibility

\begin{abstract}
A B S T R A C T
Quinoline is one of the most important heterocyclic systems in life sciences. Some derivatives are normal metabolites, and others are used as antibacterial, antimalarial, and anticancer agents. In this work, we describe the synthesis, physicochemical properties, and fluorescence features of a new 4-quinolinone fluorophore, 3-hydroxykynurenic acid (3-HOKA). 3-HOKA was obtained by alkoxide-induced rearrangement of ethyl isatinacetate followed by acidification and then alkaline hydrolysis. The fluorescent compound was characterized by NMR, MS, IR, and UV-Vis spectra. 3-HOKA can exist under a keto-enol equilibrium, but the 4-quinolinone form is the predominant tautomer. In PBS $(\mathrm{pH}=7.4)$, the anionic keto form of 3-HOKA showed a maximum absorption at $368 \mathrm{~nm}$, a fluorescence peak at $474 \mathrm{~nm}$, and a fluorescence quantum yield $\left(\Phi_{\mathrm{F}}\right): 0.73$. 3-HOKA is photostable and is a moderately weak oxygen generator. Viability assays on HeLa cells indicated that 3-HOKA did not induce significative cytotoxic effects. Under UV excitation, a bright blue fluorescence was selectively found in a singular body within the cytoplasm, a labeling pattern that suggests the possible localization of the probe in the centriole or related structures. Therefore, this novel fluorophore represents a promising prototype compound owing to its biocompatibility and potential biological applications.
\end{abstract}

\section{Introduction}

Fluorescent probes and among them quinoline-based structures, play a crucial role in bioimaging studies owing to their simple and rapid implementation, as well as their high sensitivity and high spatial resolution $[1,2]$. The use of fluorescent dyes easily functionalizable and compatible with biological experiments represents a distinctive feature for physiological research [3]. Several studies have used coumarin or quinoline scaffolds as central caged or fluorescent chemical cores to investigate small endogenous molecule functions [4]. These experiments remain limited and are highly dependent on both intrinsic biological activity and fluorescent properties of the probe (low cell and tissue penetration, biological side effects, decrease of natural function of studied molecules when labeled, among others). Moreover, the use of a small and biological inactive fluorophore coupled to the molecule of interest appears crucial to observe both its localization and its function in physiological conditions [5]. To be efficient, these fluorescent probes should be biocompatible (i.e., have low side effects at concentrations used for bioapplications) and have optimal fluorescent properties. In this context, quinolines appear quite attractive due to their relative synthetic versatility and subsequent tuning of molecular physicochemical properties [6]. For those reasons, quinoline is one of the most important heterocyclic systems, not only for its widespread inclusion in a variety of naturally occurring compounds [7], but also because many quinoline derivatives have found application in therapy, for example as antimalarial [8] and anticancer agents [9]. Quinoline-based frameworks also are key intermediates in assembling new materials with interesting electronic properties [10].

\footnotetext{
${ }^{*}$ Corresponding author.

** Corresponding author. Universidad de Buenos Aires, Instituto de Oncología Ángel H. Roffo, Área Investigación, (C1417DTB), CABA, Argentina.

E-mail addresses: mblanco@ffyb.uba.ar (M.M. Blanco), jcstockert@fvet.uba.ar (J.C. Stockert).
} 
Particularly, quinolin-4(1H)-one scaffold containing compounds represent extremely large group of organic substances that have been studied very extensively for many reasons [11]. Numerous dedicated articles can be found describing preparation and biological properties of variously substituted quinolin- $4(1 H)$-ones. When the attention is focused on a variability in position 3 of the scaffold, most of them refer to the carboxy group bearing derivatives that became familiar particularly as very successful antimicrobial agents widely used in human therapy. On the other hand, substances bearing other functional groups (i.e., hydroxy or amino group) at the 3-position have been studied less frequently [12]. When the structure is further targeted to 3-hydroxyquinolin-4(1H)-one derivatives substituted with a carboxylate at position 2, the available information decreases rapidly [13]. Considering our experience in the synthesis and study of 3-hydroxyquinolin-4(1H)-one-2-carboxylic acid derivatives [14], a family of scarcely explored 4-quinolinones, we decided to study the physicochemical and biological properties of 3-hydroxy-4-oxo-1,4-dihydroquinoline-2-carboxylic acid (3-hydroxykynurenic acid, 3-HOKA), a new fluorophore.

\section{Experimental section}

\subsection{Materials and methods}

Melting points were taken on a Büchi capillary apparatus and are uncorrected. TLC analyses were carried out on silica gel $60 \mathrm{~F}_{254}$ aluminum sheets. Preparative thin layer separations (PLC) were carried out by centrifugally accelerated radial chromatography using Chromatotron model 7924 T. The rotors were coated with Silica Gel 60 $\mathrm{PF}_{254}$ and the layer thickness was $2 \mathrm{~mm}$. Chloroform and chloroform with increasing percentages of methanol were used as eluent. Reagents, solvents and starting materials were purchased from standard sources and purified according to literature procedures. The microwave-assisted reactions were carried out in a Reactor Microwave Digestion System WX-4000, EU chemical instruments. IR spectra were recorded on a Perkin Elmer Spectrum One FT-IR spectrometer.

${ }^{1} \mathrm{H}$ and ${ }^{13} \mathrm{C}$ NMR spectra were measured in DMSO- $d_{6}$ solutions on a Bruker Avance III $600 \mathrm{MHz}$ spectrometer at $25^{\circ} \mathrm{C}$. Standard concentration of the samples was 10 and $20 \mathrm{mg} / \mathrm{mL}$, respectively. Chemical shifts are reported in ppm $(\delta$ ) relative to TMS as an internal standard. Coupling constant $(J)$ values are given in Hz. Splitting multiplicities are reported as singlet (s), broad signal (br s), broad doublet (br d), doublet $(d)$, triplet (t), quartet (q), multiplet (m), double doublet (dd), double double doublet (ddd).

High-resolution ${ }^{13} \mathrm{C}$ and ${ }^{15} \mathrm{~N}$ solid-state spectra for the 3-HOKA sample were recorded using the ramp ${ }^{1} \mathrm{H}_{-}{ }^{13} \mathrm{C}$ or ${ }^{1} \mathrm{H}_{-}{ }^{15} \mathrm{~N}$ CP-MAS sequence (cross-polarization and magic angle spinning) with proton decoupling during acquisition using the SPINAL64 sequence (small phase incremental alternation with 64 steps). All the $s s$-NMR experiments were performed at room temperature in a Bruker Avance II-300 spectrometer equipped with a 4-mm MAS probe. The operating frequency for protons, carbons and nitrogens was $300.13,75.46$ and $30.42 \mathrm{MHz}$, respectively. Ammonium chloride was used as an external reference for the ${ }^{15} \mathrm{~N}$ spectra and glycine was used as an external reference for the ${ }^{13} \mathrm{C}$ spectra and to set the Hartmann-Hahn matching condition in the crosspolarization experiments in both ${ }^{15} \mathrm{~N}$ and ${ }^{13} \mathrm{C}$ spectra. The recycling time was $4 \mathrm{~s}$. The contact time during $\mathrm{CP}$ was $1.5 \mathrm{~ms}$ for ${ }^{13} \mathrm{C}$ and $3.0 \mathrm{~ms}$ for ${ }^{15} \mathrm{~N}$ spectra. The non-quaternary suppression (NQS) and $2 \mathrm{D}^{1} \mathrm{H}_{-}-{ }^{13} \mathrm{C}$ HETCOR [15] experiments were recorded as in previous reports [16]. The contact time for the $\mathrm{CP}$ was $200 \mu$ s to avoid relayed homonuclear spin-diffusion-type processes in the $2 \mathrm{D}$ experiment. The spinning rate for all the samples was $10 \mathrm{kHz}$.

MS (EI) were recorded with a GC-MS Shimadzu QP-1000 spectrometer operating at $70 \mathrm{eV}$. High resolution mass spectra (HMRS-EI), were acquired with a model GCT (Waters, Milford, MA, USA), operating at 8000 resolving power ( $50 \%$ valley definition) using heptacose $(\mathrm{m} / \mathrm{z}$
219) as the reference compound. The HRMS-ESI spectra were acquired using a Bruker micrOTOF-QII instrument (Positive Ion Polarity).

Electronic absorption spectra were determined with a Shimadzu UV3600 PC spectrophotometer. Fluorescence spectra were monitored with a QuantaMaster Model QM-4 PTI spectrofluorometer. The emission spectra of 3-HOKA was collected at the maxima band excitation wavelength and recorded up to $700 \mathrm{~nm}$. Fluorescence quantum yields $\left(\Phi_{\mathrm{F}}\right)$ were determined by comparison with 1,3-diphenylisobenzofuran $\left(\Phi_{\mathrm{F}}=0.74\right.$ in ethanol) [17] as a reference at $\lambda \operatorname{exc}=\lambda_{\max }$. Calculations were performed by Equation (1), where $R$ and $S$ superscripts refer to the reference and the sample respectively, $I$ is the integrated area under the emission spectrum, $A$ is the absorbance of solutions at the excitation wavelength and stands for the refractive index correction.

$\Phi_{F}^{S}=\Phi_{F}^{R} \frac{I^{S}\left(1-10^{-A^{R}}\right)}{I^{R}-10^{-A^{S}}}\left(\frac{n^{S}}{n^{R}}\right)^{2}$

Standard chemical monitor bleaching rates were used to calculate the singlet oxygen $\left({ }^{1} \mathrm{O}_{2}\right)$ quantum yield $\left(\Phi_{\Delta}\right)$ [18]. For $\Phi_{\Delta}$ studies, 3HOKA was irradiated by light in the presence of imidazole and $N, N$ diethyl-4-nitrosoaniline (RNO) in $50 \mathrm{mM}$ phosphate buffer saline $\mathrm{pH}=7.4 .{ }^{1} \mathrm{O}_{2}$ generated by photo-excitation of the sensitizer reacts with imidazole to form a transannular-type peroxide which bleaches RNO, and the bleaching can be monitored spectrophotometrically at $440 \mathrm{~nm}$ as a function of time. The reaction was carried out in $50 \mathrm{mM}$ phosphate buffer saline solution (PBS), $\mathrm{pH}=7.4$ with imidazole $(10 \mathrm{mM})$ and RNO $(50 \mu \mathrm{M})$. The quantum yield for ${ }^{1} \mathrm{O}_{2}$ generation was determined for 3-HOKA by measuring the relative rates of RNO bleaching under identical conditions after correcting for the incident light, using rose bengal as reference $\Phi_{\Delta}=0.76$ [19]. 3-HOKA and the reference were irradiated within the same wavelength interval $\lambda_{1}-\lambda_{2}$ and $\Phi_{\Delta}$ was calculated according to Equation (2) [20], where $r$ is the ${ }^{1} \mathrm{O}_{2}$ photogeneration rate and the superscripts $S$ and $R$ stand for the sample and reference respectively, $A$ is the absorbance at the irradiation wavelength and $I_{\mathrm{o}}(\lambda)$ is the incident spectral photon flow (mol s${ }^{-1}$ $\mathrm{nm}^{-1}$ ). When the irradiation wavelength range is narrow, the incident intensity varies smoothly with wavelength and the sample and reference have overlapping spectra, $I_{\mathrm{o}}$ may be approximated by a constant value which may be drawn out of the integrals and cancelled. Experiments exciting 3-HOKA were performed in a polychromatic set-up using a projector lamp (Philips 7748SEHJ, $250 \mathrm{~W}$ ).

$\Phi_{\Delta}^{S}=\Phi_{\Delta}^{R} \frac{r^{2} \int_{\lambda_{1}}^{\lambda_{2}} I_{0}(\lambda)\left(1-10^{-A^{R(\lambda)}}\right) d \lambda}{r^{R} \int_{\lambda_{1}}^{\lambda_{2}} I_{0}(\lambda)\left(1-10^{-A^{S}(\lambda)}\right) d \lambda}$

The photostability of 3-HOKA was analyzed in PBS by measuring the decrease in the intensity of the $\lambda_{\max }$ over time irradiation with a visible light of $350-850 \mathrm{~nm}$ from a $250 \mathrm{~W}$ halogen lamp [21]. The fluence rate was adjusted to $20 \mathrm{mWcm}^{-2}$. Measurements were performed under air in PBS. Photodegradation rate constants $k$ were calculated by Equation (3), where $\mathrm{t}, A_{0}, A_{\mathrm{t}}$ are their radiation time, absorbance at $\mathrm{t}=0$, absorbance at different times, respectively. 1,3Diphenylisobenzofuran (DPBF), N,N-diethyl-4-nitrosoaniline (RNO), ethanol and PBS were available commercially and used without further purification.

$\ln \frac{A_{0}}{A_{t}}=k \mathrm{t}$

\subsection{Synthesis and physicochemical characterization}

2.2.1. Synthesis of 3-hydroxy-4-oxo-1,4-dihydroquinoline-2-carboxylic acid (3-HOKA) from kynurenic acid (KA)

a Employing the methodology for the oxidation of phenols described by Elbs [22], 3-hydroxykynurenic acid (3-hydroxy-4-oxo-1,4- 
dihydroquinoline-2-carboxylic acid, 28\%) was obtained from kynurenic acid. No other hydroxylating agents such $\mathrm{Mn}(\mathrm{AcO})_{3}, \mathrm{~Pb}$ $(\mathrm{AcO})_{4}$ or Fenton's reagent gave successful results.

b To a suspension of the kynurenic acid ethyl ester (100 mg, $0.46 \mathrm{mmol})$ in water $(10 \mathrm{~mL})$ at $-10^{\circ} \mathrm{C}$, NBS $(82.5 \mathrm{mg}, 0.46 \mathrm{mmol})$ was added and stirred for about $3 \mathrm{~h}$. The reaction was monitored by TLC $\left(\mathrm{CHCl}_{3}: \mathrm{MeOH}, 9: 1\right)$ until the disappearance of the starting compound. The solid obtained, 3-bromo-4-oxo-1,4-dihydroquinoline-2-carboxylic acid ethyl ester (94\%), was filtered, washed with cold water, dried and recrystallized. By treatment of 3-bromo-4-oxo1,4-dihydroquinoline-2-carboxylic acid ethyl ester with $10 \% \mathrm{NaOH}$ at $40{ }^{\circ} \mathrm{C}$, or $30 \% \mathrm{NaOH}$ under reflux (by conventional heating or by microwave irradiation for $30 \mathrm{~min}$ at $800 \mathrm{~W}$ ), 3-bromo-4-oxo-1,4-dihydroquinoline-2-carboxylic acid (91\%) was obtained.

Hydroxylation of KA employing horseradish and soybean peroxidases (HRP and SBP), under different conditions, gave unsuccessful results.

\subsubsection{Synthesis of 3-hydroxy-4-oxo-1,4-dihydroquinoline-2-carboxylic} acid (3-HOKA) from ethyl isatinacetate (EIA)

Ethyl isatinacetate ((2,3-dioxo-2,3-dihydroindol-1-yl)acetic acid ethyl ester, EIA) was obtained following literature procedure [14c].

To a solution of sodium alkoxide prepared from sodium (350 mg, $15.2 \mathrm{mmol})$ in anhydrous ethanol $(7.6 \mathrm{~mL})$ under argon and heated in an oil bath $\left(100-120^{\circ} \mathrm{C}\right)$, EIA $(3.8 \mathrm{mmol})$ was added as a powder in one portion. After $5-10 \mathrm{~min}$ the reaction mixture was poured into ice- $\mathrm{HCl}$ and extracted with $\mathrm{CHCl}_{3}(3 \times 10 \mathrm{~mL})$. The organic layers were pooled, washed with water, dried with $\mathrm{Na}_{2} \mathrm{SO}_{4}$, filtered and evaporated in vacuo. Separation of the compounds obtained was achieved by centrifugal PLC. The first band eluted gave the ethyl 3-hydroxy-4-oxo-1,4dihydroquinoline-2-carboxylate (65\%). The slower moving band afforded traces of 3-HOKA.

A mixture of ethyl 3-hydroxy-4-oxo-1,4-dihydroquinoline-2-carboxylate $(699 \mathrm{mg}, 3 \mathrm{mmol})$ with $2 \mathrm{~N}$ sodium hydroxide $(3 \mathrm{~mL})$ was heated on a water bath to $70^{\circ} \mathrm{C}$ during $5 \mathrm{~min}$. The solution was quickly cooled in an ice bath and by slow acidification with $10 \% \mathrm{HCl}$, 3-hydroxy-4-oxo-1,4-dihydroquinoline-2-carboxylic acid (3-HOKA) precipitates quantitatively.

\subsubsection{Analytical data of the synthesized compounds}

2.2.3.1. 3-Hydroxy-4-oxo-1,4-dihydroquinoline-2-carboxylic acid (3HOKA). Light brown powder, easily detected by TLC due to intense light blue fluorescence under UV irradiation $(256 \mathrm{~nm})$ when it is adsorbed on chromatographic supports. Mp: $260-262^{\circ} \mathrm{C}$ (propanone) lit. 261-262 ${ }^{\circ} \mathrm{C}$ [23,24]; pKa: 2.2 and 3.9; IR (KBr): 3419, 3001, 2360, 1666, 1631, 1473, 1346, 1286, 918, $764 \mathrm{~cm}^{-1}$ among others; ${ }^{1} \mathrm{H}$ NMR (DMSO- $\left.d_{6}\right): \delta=8.16$ (d, $\left.J=8.3 \mathrm{~Hz}, 1 \mathrm{H}, \mathrm{H}-5\right), 8.12(\mathrm{~d}, J=8.5 \mathrm{~Hz}, 1 \mathrm{H}$, $\mathrm{H}-8$ ), 7.73 (ddd, $J=8.5 ; 6.8 ; 1,4 \mathrm{~Hz}, 1 \mathrm{H}, \mathrm{H}-7), 7.46$ (t, $J=7.6 \mathrm{~Hz}, 1 \mathrm{H}$, H-6); ${ }^{13} \mathrm{C}$ NMR (DMSO- $d_{6}$ ): $\delta=165.1$ (C-9), 164.7 (C-4), 143.9 (C-2), 136.2 (C-8a), 132.1 (C-7), 126.6 (C-3), 125.1 (C-6), 123.8 (C-5), 121.6 (C-4a), 120.3 (C-8); MS (EI, $70 \mathrm{eV}): m / z(\%)=205(53)[\mathrm{M}]^{+}, 103$ (100); HRMS-ESI: $\mathrm{m} / \mathrm{z}$ calcd. for $\mathrm{C}_{10} \mathrm{H}_{8} \mathrm{NO}_{4}: 206.04478[\mathrm{M}+\mathrm{H}]^{+}$, found: 206.04400. (See Supporting Information).

2.2.3.2. 3-Hydroxy-4-oxo-1,4-dihydroquinoline-2-carboxylic acid ethyl ester. White crystals, mp: $243-244^{\circ} \mathrm{C}$ (methanol); IR (KBr): 3300 , 3143, 3111, 2983, 2692, 1702, 1662, 1528, 1427, 1263, $750 \mathrm{~cm}^{-1}$ among others; ${ }^{1} \mathrm{H}$ NMR (DMSO- $d_{6}$ ): $\delta=12.74$ (br s, $1 \mathrm{H}, \mathrm{OH}$ ), $12.50(\mathrm{br}$ s, $1 \mathrm{H}, \mathrm{NH}$ ), 8.02 (d, $J=8.1 \mathrm{~Hz}, 1 \mathrm{H}, \mathrm{H}-5), 7.52$ (d, $J=8.1 \mathrm{~Hz}, 1 \mathrm{H}, \mathrm{H}-8)$, 7.34 (t, $J=8.1 \mathrm{~Hz}, 1 \mathrm{H}, \mathrm{H}-7$ ), 7.22 (t, $J=8.1 \mathrm{~Hz}, 1 \mathrm{H}, \mathrm{H}-6), 4.40$ (q, $J=7.1 \mathrm{~Hz}, 2 \mathrm{H}, \mathrm{CH}_{2}$ ), 1.37 (t, $\left.J=7.1 \mathrm{~Hz}, 3 \mathrm{H}, \mathrm{CH}_{3}\right) ;{ }^{13} \mathrm{C} \mathrm{NMR}$ (DMSO- $\left.d_{6}\right): \delta=165.1$ (C-4), $162.4\left(\mathrm{CO}_{2}\right), 135.7$ (C-8a), 129.7 (C-2), 126.7 (C-4a), 125.4 (C-7), 122.5 (C-6), 122.3 (C-5), 113.2 (C-8), 111.1 (C-3), $62.2\left(\mathrm{CH}_{2}\right), 14.1\left(\mathrm{CH}_{3}\right)$; HRMS-EI: $\mathrm{m} / \mathrm{z}$ calcd for $\mathrm{C}_{12} \mathrm{H}_{11} \mathrm{NO}_{4}$ : 233.068807 [M] ${ }^{+}$; found: 233.068470 .
2.2.3.3. 3-Bromo-4-oxo-1,4-dihydroquinoline-2-carboxylic acid. Offwhite powder, mp: $289-290{ }^{\circ} \mathrm{C}$ (methanol) lit. $290{ }^{\circ} \mathrm{C}$ [24]; ${ }^{1} \mathrm{H}$ NMR (DMSO- $d_{6}$ ): $\delta=11.93$ (br s, $1 \mathrm{H}, \mathrm{NH} / \mathrm{OH}$ ), 11.90 (br s, $1 \mathrm{H}, \mathrm{NH} / \mathrm{OH}$ ), 8.04 (dd, $J=7.9,1.5 \mathrm{~Hz}, 1 \mathrm{H}, \mathrm{H}-5$ ), 7.66 (br d, $J=8.2 \mathrm{~Hz}, 1 \mathrm{H}, \mathrm{H}-8$ ), 7.58 (ddd, $J=8.2,6.8,1.5 \mathrm{~Hz}, 1 \mathrm{H}, \mathrm{H}-7$ ), 7.26 (ddd, $J=7.9,6.8$, $1.2 \mathrm{~Hz}, 1 \mathrm{H}, \mathrm{H}-6)$.

2.2.3.4. 3-Bromo-4-oxo-1,4-dihydroquinoline-2-carboxylic acid ethyl ester. White powder, mp: $251-252{ }^{\circ} \mathrm{C}$ (ethanol) lit. $250-251{ }^{\circ} \mathrm{C}$ [25]; ${ }^{1} \mathrm{H}$ NMR (DMSO- $d_{6}$ ): $\delta=12.77$ (br s, $\left.1 \mathrm{H}, \mathrm{NH}\right), 8.13(\mathrm{~d}, J=8.2 \mathrm{~Hz}, 1 \mathrm{H}$, $\mathrm{H}-5$ ), 7.75-7.69 (m, 2H, H-7 and H-8), 7.40 (t, $J=8.2 \mathrm{~Hz}, 1 \mathrm{H}, \mathrm{H}-6$ ), 4.46 (q, $J=7.2 \mathrm{~Hz}, 2 \mathrm{H}, \mathrm{CH}_{2}$ ), 1.37 (t, $\left.J=7.2 \mathrm{~Hz}, 3 \mathrm{H}, \mathrm{CH}_{3}\right) ;{ }^{13} \mathrm{C} \mathrm{NMR}$ (DMSO- $d_{6}$ ): $\delta=164.2$ and $161.9\left(\mathrm{CO}_{2}\right.$ and C-4), 140.8 and $138.5(\mathrm{C}-2$ and C-8a), 132.9 (C-7), 125.3 (C-5), 124.9 (C-6), 123.4 (C-4a), 118.9 (C-8), $104.9(\mathrm{C}-3), 63.2\left(\mathrm{CH}_{2}\right), 13.8\left(\mathrm{CH}_{3}\right)$.

\subsection{Biological tests}

HeLa cells (human cervix adenocarcinoma ATCC ${ }^{\circ}$ CCL- $2^{\mathrm{TM}}$ ) were grown on $22 \mathrm{~mm}$ square coverslips placed into $35 \mathrm{~mm}$ culture dishes using Dulbecco's modified Eagle's medium (DMEM) containing 10\% (v/ v) fetal bovine serum, $50 \mathrm{U} / \mathrm{mL}$ penicillin, $50 \mathrm{mg} / \mathrm{mL}$ streptomycin and $1 \%$ (v/v) $0.2 \mathrm{M}$ L-glutamine (complete DMEM; all products from Gibco, Paisley, Scotland, UK). Cultures were maintained at $37{ }^{\circ} \mathrm{C}$ in a humidified atmosphere containing $5 \% \mathrm{CO}_{2}$, and the culture medium was changed daily. Experiments were done during the exponential phase of cell growth.

A stock $1 \mathrm{mg} / \mathrm{mL}$ solution of 3-HOKA was prepared in PBS, filtered through a Millipore $0.22 \mu \mathrm{m}$ filter (Merck SLGP033RB), and then diluted with complete DMEM to reach the final concentrations: $10 \mu \mathrm{g} \mathrm{mL} \mathrm{m}^{-1}, 50 \mu \mathrm{gL}^{-1}$, and $100 \mu \mathrm{gL}^{-1}$. Cells were subjected to these 3-HOKA concentrations for 3 and $18 \mathrm{~h}$ in the dark, which were chosen as representative incubation times to analyze possible early and late effects. After 3-HOKA treatments and PBS washing, cells were again incubated for $24 \mathrm{~h}$ in the dark with complete culture medium, and then studies on the cell morphology and viability were performed. Cellular morphology was analyzed in living cells under phase contrast, differential interference contrast (DIC), or using bright-field microscopy after fixation with cold methanol $\left(-20^{\circ} \mathrm{C}\right)$ for $5 \mathrm{~min}$ [26], and with formaldehyde vapor in a moist chamber for different times [27]. Methanol-fixed cells were stained with $0.1 \%$ neutral red in distilled water for 2 min, washed, air-dried, and mounted in DePeX.

Cell viability was assessed by means of 3-(4,5-dimethylthiazol-2-yl)2,5-diphenyl-tetrazolium bromide (MTT) assay [28]. Briefly, cell cultures were subjected to $0.05 \mathrm{mg} / \mathrm{mL}$ MTT in complete DMEM for $3 \mathrm{~h}$, the medium was discarded, and the purple formazan product formed by reduction of MTT in viable cells were solubilized with pure DMSO. The formazan concentration was determined by absorption at $562 \mathrm{~nm}$ using a Synergy HT spectrophotometer (BioTek; Winooski, VT, USA). Cell viability was assessed by the ratio between the absorbance of treated cells and that of non-treated cells (control, 100\% viability). Results were the mean values and standard deviation (SD) from at least three different experiments in triplicate. Statistical analysis was performed using one-way ANOVA with Tukey's post-test.

Microscopic observations and photography were performed using an inverted microscope Leica DM IL LED (Wetzlar, Germany), equipped with a digital camera DFC420, phase contrast, and DIC optics. An epifluorescence microscope Olympus BX61 and a digital camera Olympus DP50 (Center Valley, PA, USA) were used for fluorescence observations and photography under UV excitation $(365-390 \mathrm{~nm}$ ), generally with an exposure time of $3 \mathrm{~s}$. Image processing and analysis (IPA) was performed using Adobe Photoshop CC2017, and the free FIJI software (http://fiji.sc/Fiji). 
<smiles>CC=C(C)C</smiles><smiles>CCOC(=O)CN1C(=O)C(=O)c2ccccc21</smiles><smiles>C=C1C(O)=C(C(=O)OCC)Nc2ccccc21</smiles>

Scheme 1. Synthesis routes of the 3-HOKA: [a] 1) $\mathrm{K}_{2} \mathrm{~S}_{2} \mathrm{O}_{8}, \mathrm{NaOH}, \mathrm{H}_{2} \mathrm{O}$, r.t., $\left.12 \mathrm{~h}, 2) 1 \mathrm{~N} \mathrm{HCl}, 100^{\circ} \mathrm{C}, 1 \mathrm{~h} \mathrm{[b]} \mathrm{1)} \mathrm{NBS,} \mathrm{H}_{2} \mathrm{O},-10^{\circ} \mathrm{C}, 3 \mathrm{~h}, 2\right) 30 \% \mathrm{NaOH}, \mathrm{MW}$ $30 \mathrm{~min}, 800 \mathrm{~W}$ [c] 1) NaOEt/EtOH, $\left.110-120^{\circ} \mathrm{C}, 5-10 \mathrm{~min}, 2\right)$ ice-HCl. [d] 1) $2 \mathrm{~N}$ $\left.\mathrm{NaOH}, 70^{\circ} \mathrm{C}, 5 \mathrm{~min}, 2\right) 10 \% \mathrm{HCl}$.

\section{Results and discussion}

\subsection{Synthesis}

3-HOKA can be obtained from the preformed 4-quinolinone nucleus, by C-3 hydroxylation of commercially available kynurenic (KA) acid. Oxidation using peroxydisulfate in basic media (Elbs' reaction) [22] afforded poor 3-HOKA yields (28\%). Alternatively, the halogenationhydrolysis sequence [24] failed. On the other hand, by alkoxide-induced rearrangement of ethyl isatinacetate (EIA) with 4 equivalents of sodium ethoxide in anhydrous ethanol at $110-120^{\circ} \mathrm{C}$ followed by acidification with ice-HCl, we obtained mixtures of varying amounts of 3-HOKA together with ethyl 3-hydroxy-4-oxo-1,4-dihydroquinoline-2carboxylate (65\%) [14c]. The latter yielded quantitatively 3-HOKA by alkaline hydrolysis. Unlike other families of compounds with enolic form of carbonyl group $(\mathrm{C}=\mathrm{O})$ (isoquinolinones and naphthyridinones), 3-hydroxyquinolinones do not give a positive reaction with $\mathrm{FeCl}_{3}$. The 3-HOKA structure was confirmed by spectral analysis (Scheme 1).

3-HOKA can exist under a tautomeric equilibrium with three intramolecular hydrogen bonds that involve parts of the molecule with conjugated $\pi$ bonds, forming an electronic $\pi$ planar system (Fig. 1). The stabilization achieved through these hydrogen bonds assisted by resonance ( $R A H B$ effect) would be responsible for the physicochemical properties observed (high insolubility in most solvents, low reactivity of the heterocyclic ring, fluorescence, among others).

\subsection{Physicochemical properties}

From the analysis of the NMR spectra (DMSO- $d_{6}$ ) it appears that the keto form $\mathbf{A}$ is the only one observed in solution. In the IR spectrum $(\mathrm{KBr})$, a wide band of low to medium intensity at $2200-3500 \mathrm{~cm}^{-1}$, corresponding to associated $\mathrm{O}-\mathrm{H} / \mathrm{N}-\mathrm{H}$ stretches, was observed.

The $s s$-NMR studies were crucial to study structurally the 3-HOKA

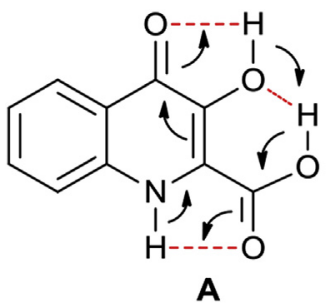<smiles></smiles>

Fig. 1. Tautomeric equilibrium of 3-HOKA. molecule, obtaining information in the solid-state when a monocrystalline sample is difficult to be obtained [16a,29]. For the 3-HOKA sample, both ${ }^{15} \mathrm{~N}$ and ${ }^{13} \mathrm{C}$ CP-MAS spectra show that only one molecule per unit cell is present since only one nitrogen resonance signal is present $\left(\delta^{15} \mathrm{~N}=-222.4 \mathrm{ppm}\right)$, while the ${ }^{13} \mathrm{C}$ CP-MAS spectrum shows nine signals when this molecule has ten carbons (Fig. 2, Table 1). Additionally, the ${ }^{15} \mathrm{~N}$ resonance signal of the 3-HOKA was quite similar to the reported value in ciprofloxacin derivatives where the 4-quinolone forms are the predominant tautomer [29b]. The assignment of the ${ }^{13} \mathrm{C}$ CP-MAS spectrum was done according to the NQS and solution-state NMR experiments presented here. In the NQS experiment, the resonance signals of the quaternary carbons are only observed allowing the assignment of the carbons bounded to hydrogens (C-5-8) in the ${ }^{13} \mathrm{C}$ CP-MAS spectrum, however, the unequivocal assignment of the NMR signals was done according to the $2 \mathrm{D}{ }^{1} \mathrm{H}^{-}{ }^{13} \mathrm{C}$ HETCOR experiment (Fig. 3). In this $2 \mathrm{D}$ experiments, the different ${ }^{13} \mathrm{C}$ nuclei correlated with the protons that were directly linked or nearby (inset in Fig. 3), doing possible to study the predominant tautomeric form and the connectivity and disposition of the different functional groups in the 3-HOKA molecule. The indirect ${ }^{1} \mathrm{H}$ dimension shows two set of signals at 7-8 and 12-13 ppm corresponding to the aromatic hydrogens and hydrogens bounded to heteroatoms, respectively. Particularly, the long-range interactions $\mathrm{B}, \mathrm{C}, \mathrm{D}$ and $\mathrm{K}$ were essential to assume that 4-quinolone form is the predominant tautomeric of 3-HOKA either in the solid state or in solution (Fig. 3). Moreover, the unequivocal assignment of the C-4 and the carboxylic acid was done considering that only the C-4 was close and interacted with the aromatic proton $\mathrm{H}-5$ (correlation B, Fig. 3). The carboxylic acid carbon (C-9) was only near to its own acidic proton at $12.6 \mathrm{ppm}$ (correlation A, Fig. 3). Furthermore, three different protons corresponding to the $-\mathrm{OH}\left(\delta^{1} \mathrm{H}=13.1\right)$, $-\mathrm{NH}\left(\delta^{1} \mathrm{H}=12.3\right)$ and $-\mathrm{CO}_{2} \mathrm{H}$ $\left(\delta^{1} \mathrm{H}=12.6 \mathrm{ppm}\right)$ were well-resolved in the 2D spectrum. Interestingly, the $\mathrm{H}-8$ presents a higher proton chemical shift $\left(\delta^{1} \mathrm{H}=8.4 \mathrm{ppm}\right)$ than the rest of the aromatic protons $\left(\delta^{1} \mathrm{H} \sim 7.6-7.7 \mathrm{ppm}\right)$ being different to those observed in solution-state NMR, allowing the correct assignment of C-8a and $\mathrm{NH}$ due to the long-range interaction D and C, respectively (Fig. 2). It is important to mention, that the ${ }^{1} \mathrm{H}$ chemical shift of $\mathrm{H}-5-8$ is particularly affected depending on the deuterated solvents used in the solution-state NMR experiments.

The absorption spectra in different media are like other kynurenic acid derivatives previously reported [30]. Due to the presence of ionizable groups on the quinoline ring, the location and the intensity of the bands are strongly affected by $\mathrm{pH}$ changes. In $\mathrm{PBS}(\mathrm{pH}=7.4)$, the maximum absorption is centered at $\lambda 368 \mathrm{~nm}$, whereas in DMF it is positioned at $\lambda 386 \mathrm{~nm}$ (Fig. 4). This red shift indicates that H-bonding occurs between the oxygen of the solvent and the hydrogen of the 3HOKA carboxylic function which is probably not ionized in DMF [31]. Based on the previous literature, $\lambda_{\max }$ absorption band in neutral aqueous media has been assigned to the anionic keto form, and in other organic solvents such as DMF, the main contribution of the absorption band arises from the neutral keto tautomer species [32].

A single fluorescence band is observed (DMF or PBS) when 3-HOKA is excited at the $\lambda_{\max }$ suggesting that 3-HOKA exists only in the keto form in both media (Fig. 4). The fluorescence $\lambda_{\max }$ of 3-HOKA in DMF is shifted $\sim 8 \mathrm{~nm}$ to the red in comparison to the $\lambda_{\max }$ observed in PBS, which is consistent with other previously studies [32]. 3-HOKA presented a high value of fluorescence quantum yield in DMF $\left(\Phi_{\mathrm{F}}=0.77 \pm 0.024\right)$ as well as in $\mathrm{PBS}\left(\Phi_{\mathrm{F}}=0.73 \pm 0.033\right)$ which indicates the great potential of 3-HOKA as a fluorescence labeling agent. Using the $N, N$-dimethyl-4-nitrosoaniline (RNO) bleaching method, 3-HOKA showed low values of singlet oxygen quantum yield $\left(\Phi_{\Delta}\right)$ in $\operatorname{DMF}\left(\Phi_{\Delta}=0.06 \pm 0.002\right)$ and $\operatorname{PBS}\left(\Phi_{\Delta}=0.04 \pm 0.001\right)$, suggesting that is a moderately weak oxygen generator. The photostability was analyzed in PBS. The decay time of the $\lambda_{\max }$ followed a first-order kinetics. 3-HOKA showed a low value of $\mathrm{k}$ (0.0007), which indicates that it is stable during the irradiation time of our experiments. 


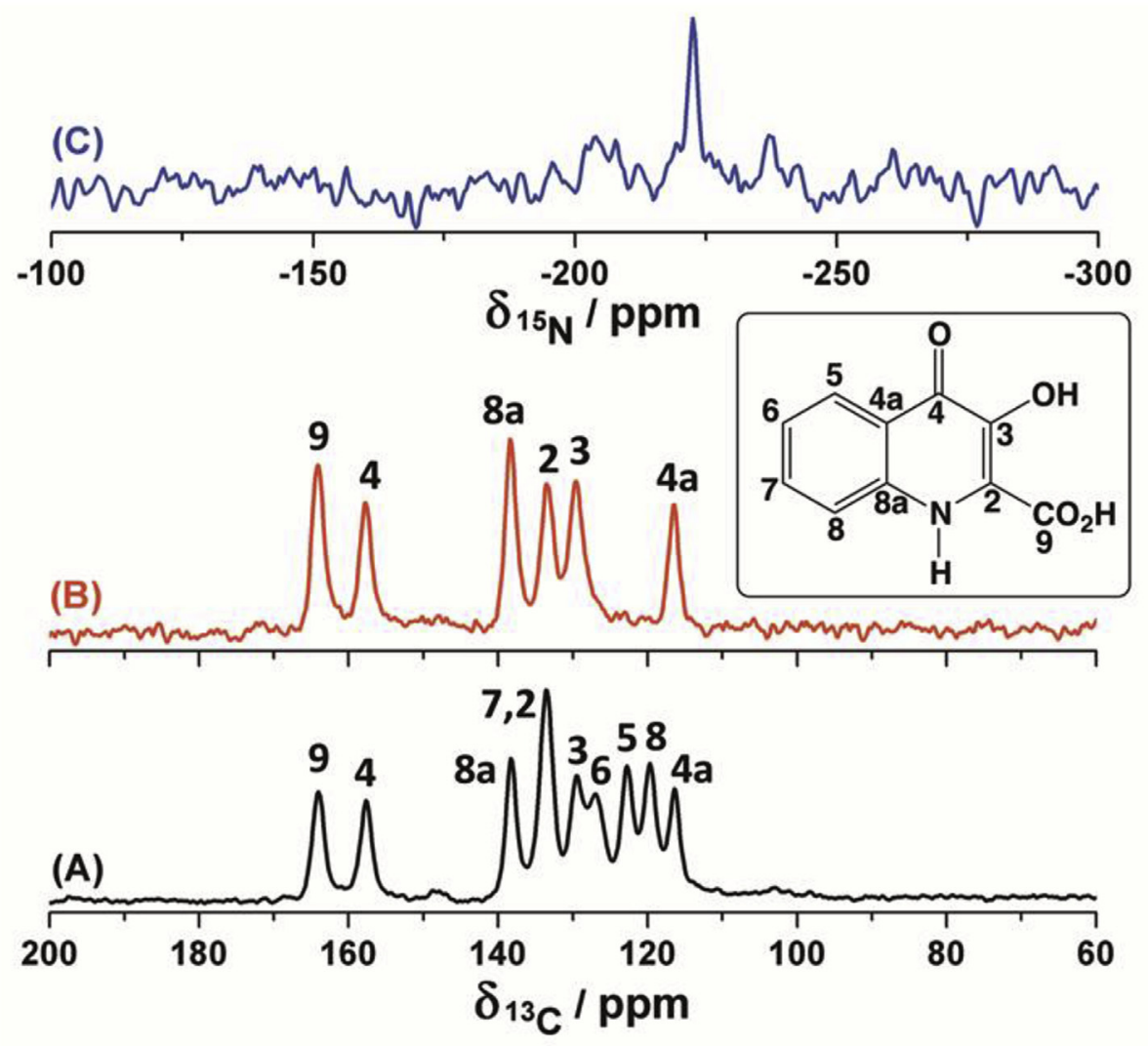

Fig. 2. ${ }^{13} \mathrm{C}$ CP-MAS (A), NQS (B) and ${ }^{15} \mathrm{~N}$ CP-MAS (C) spectra for the 3-HOKA.

Table 1

${ }^{13} \mathrm{C}$ NMR chemical shifts of 3-HOKA observed in solid state and in solution .

\begin{tabular}{|c|c|c|c|c|c|c|c|c|c|c|}
\hline \multirow[t]{2}{*}{ NMR experiments } & \multicolumn{10}{|c|}{ Chemical shifts (ppm) } \\
\hline & C-2 & $\mathrm{C}-3$ & C-4 & C-4a & C-5 & C-6 6 & C-7 & C-8 & C-8a & C-9 \\
\hline Solution & 143.9 & 126.6 & 164.7 & 121.6 & 123.8 & 125.1 & 132.1 & 120.3 & 136.2 & 165.1 \\
\hline Solid-state & $133.6^{*}$ & 129.5 & 157.7 & 116.5 & 122.8 & 127.1 & $133.6^{*}$ & 119.8 & 138.3 & 164.1 \\
\hline
\end{tabular}

\subsection{Cell viability assay}

No morphological changes were observed in living HeLa cells treated with different concentrations of 3-HOKA after short $(3 \mathrm{~h})$ or prolonged times $(18 \mathrm{~h})$. Cell cultures showed a completely normal morphology and the cell density was the same as that of untreated controls (Fig. 5). Mitotic cells were also clearly detected even at the highest 3-HOKA concentration and treatment time. Likewise, different 3-HOKA treatments do not produce significative cytotoxic effects as revealed by the MTT assay, and the cell viability appeared very well conserved (Fig. 6).

\subsection{Application in cell imaging}

In HeLa cells treated for $3 \mathrm{~h}$ with 3-HOKA at any concentration only a blue signal in granular components resembling lysosomes was sometimes observed, and likewise, poorly resolved mitochondrial structures were also detected, but in both cases the weak signal and diffuse cytoplasmic emission hindered their precise visualization. However, after $18 \mathrm{~h}$ treatment with 3-HOKA, a perinuclear or peripheral body with high blue fluorescence could be very often visualized within the cytoplasm of living cells (Fig. 7). Granular, crystalloid, arrowhead, cross- or L-shaped forms were the most frequent aspect of this body. Because its appearance, this structure will be referred as the "singular body". It was clearly observed using the three 3HOKA concentrations, but in untreated controls or in cells treated for only $3 \mathrm{~h}$ this body was not found.

After treatments for 3 or $18 \mathrm{~h}$, the 3-HOKA fluorescence showed considerable fading, and therefore prolonged observations under UV exciting light could be not performed. On the other hand, a fluorescent structure, very like the singular body, was often observed in the intercellular bridge connecting two daughter cells after mitosis (Fig. 8). It is known that this bridge contains the persisting midbody formed by remaining spindle microtubules, which appear interdigitated and tightly packed together with a dense matrix material [33]. Attempts made for fixing treated cells to preserve the fluorescent 3-HOKA signal were unsuccessful. The fixation with formaldehyde vapor for $1 \mathrm{~min}$ greatly reduced or abolished the 3-HOKA emission of the singular body, whereas fixing for 5 or $10 \mathrm{~min}$ generated too much formaldehyde-induced fluorescence that obliterated any other signal. However, because 


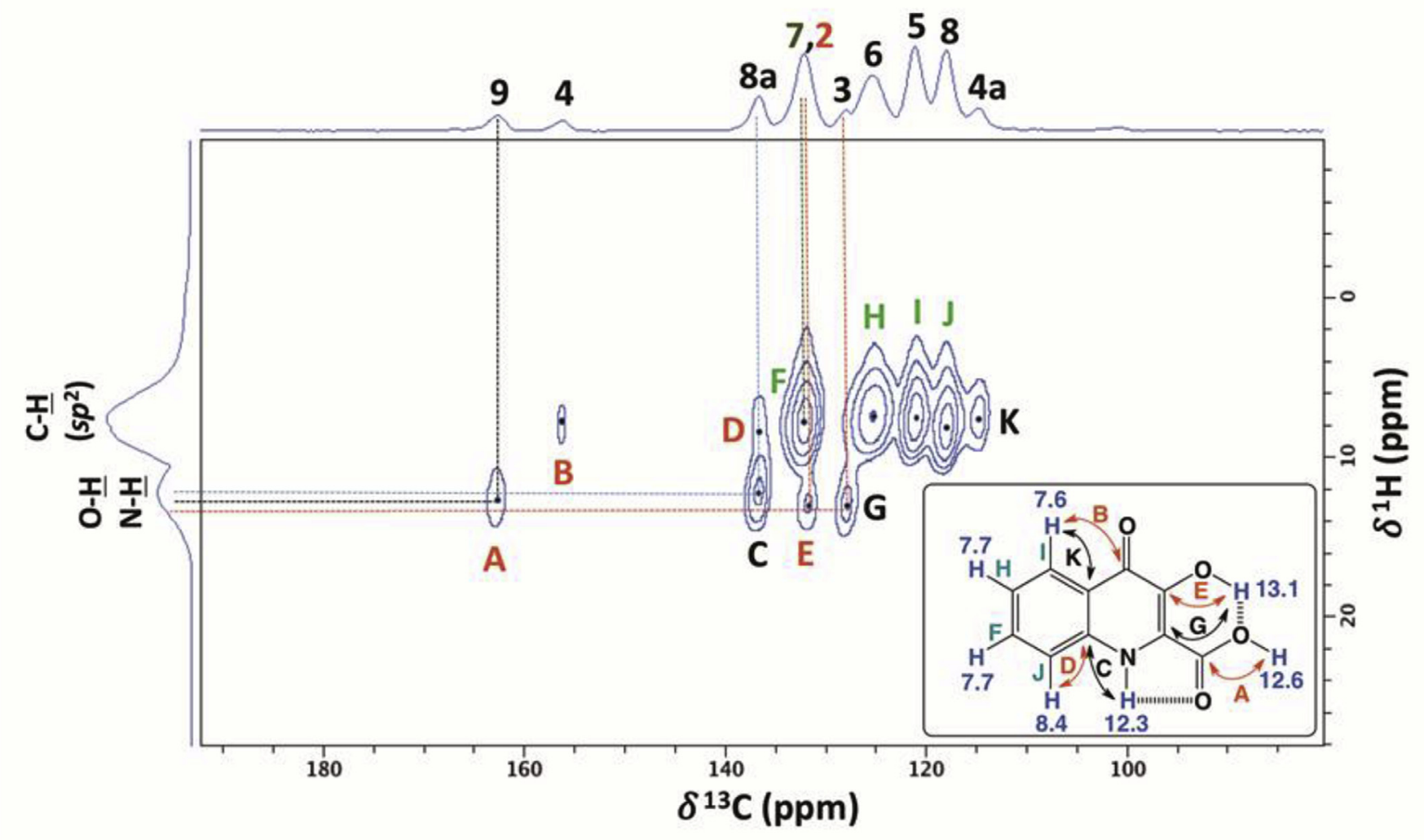

Fig. 3. $2 \mathrm{D}{ }^{1} \mathrm{H}-{ }^{13} \mathrm{C}$ HETCOR spectrum for the 3-HOKA sample.

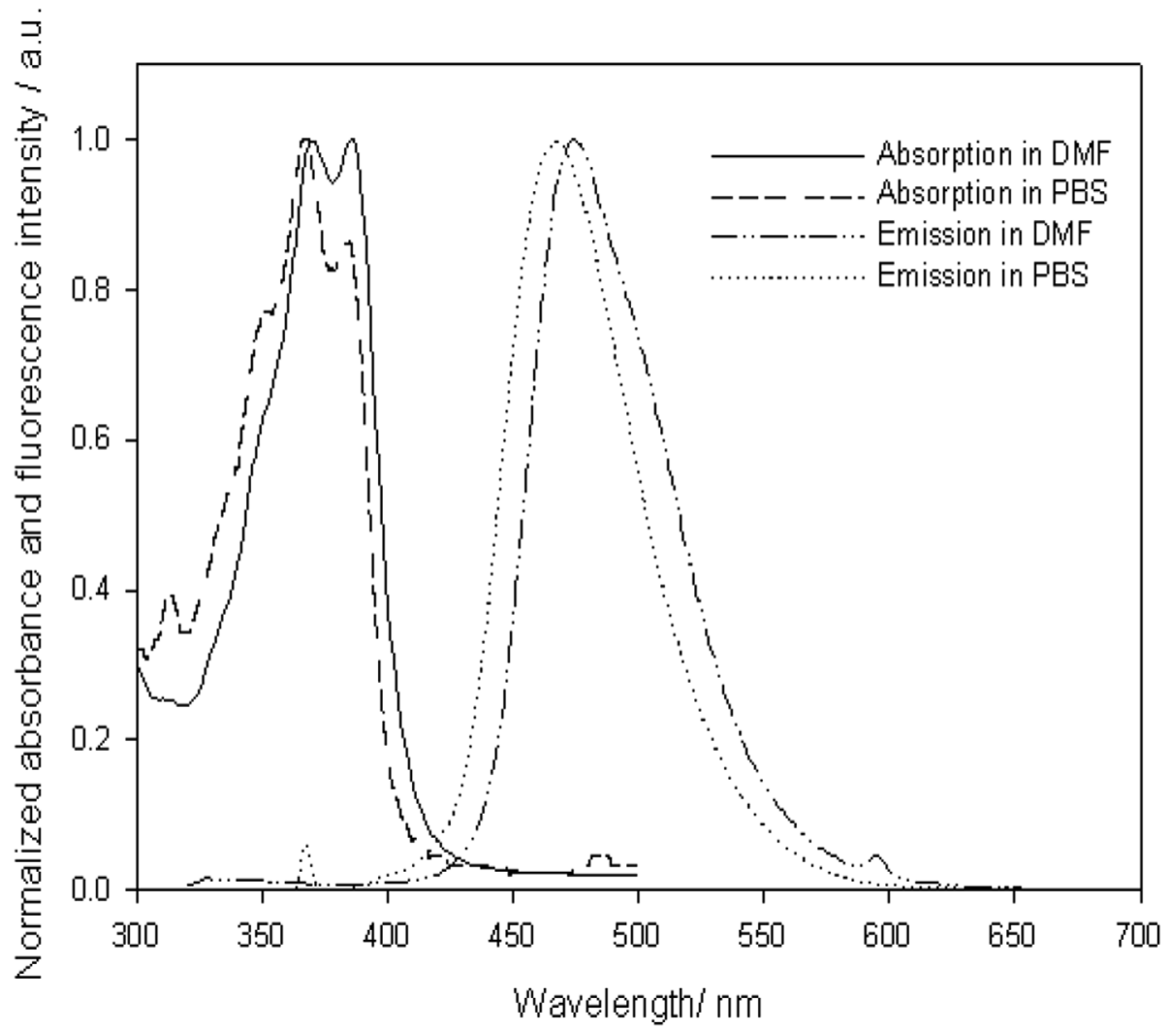

Fig. 4. Normalized UV-Vis absorption and emission spectra of 3-HOKA $(12 \mu \mathrm{M})$ in DMF and PBS $(\mathrm{pH}=7.4)$. 
Control
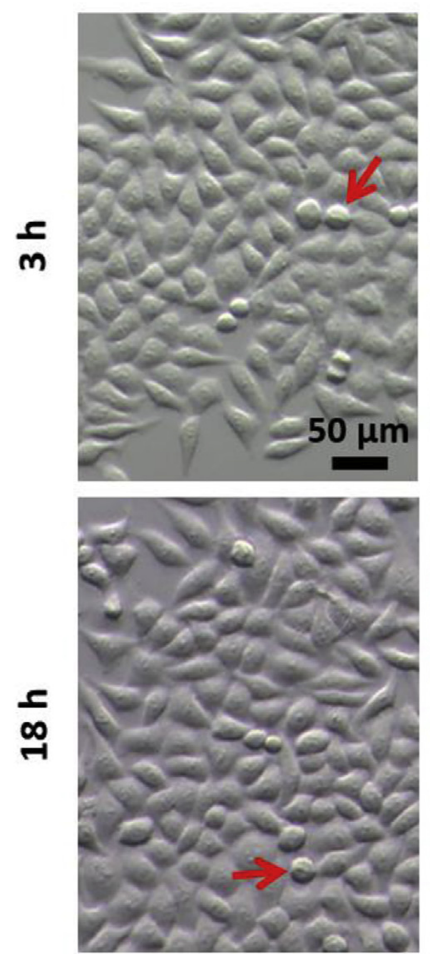

$10 \mu \mathrm{g} / \mathrm{mL}$
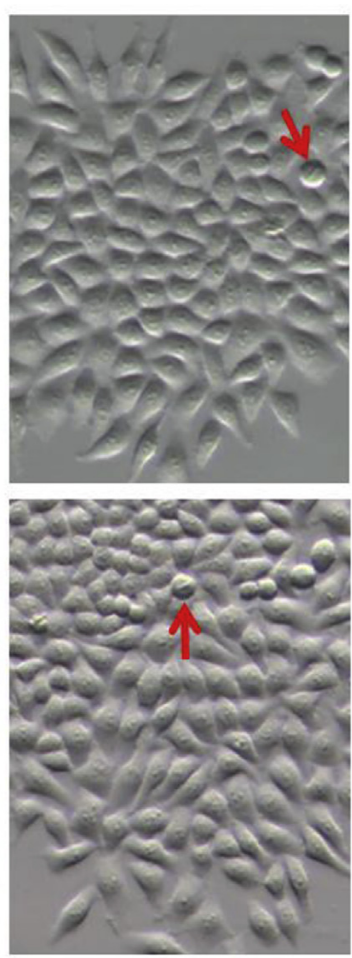

$50 \mu \mathrm{g} / \mathrm{mL}$
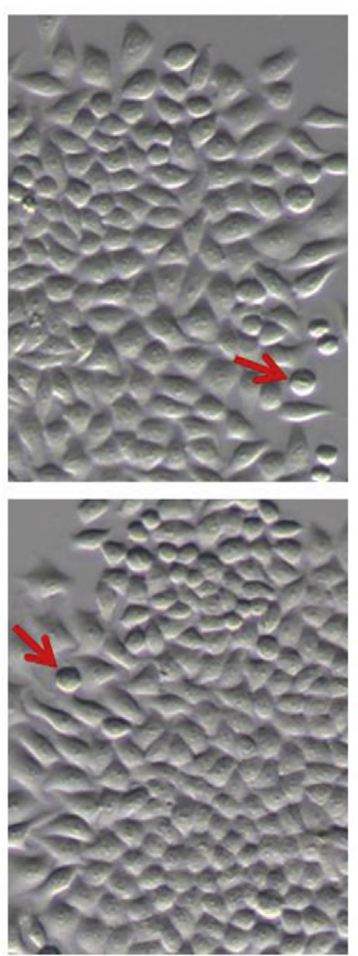

$100 \mu \mathrm{g} / \mathrm{mL}$
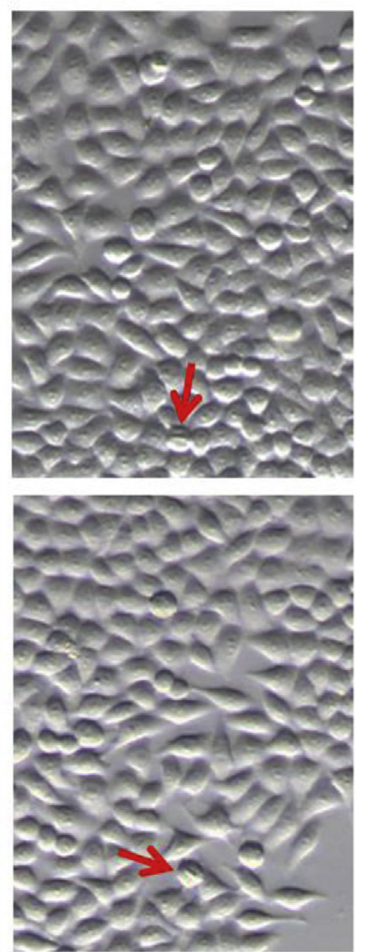

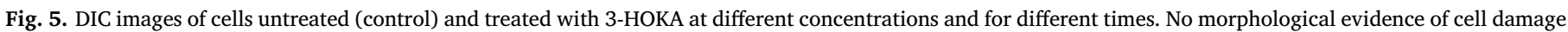
can be seen. Arrows indicate metaphase cells, showing the equatorial plate as a steep central bar.

the low density of the cell periphery, the fluorescent body located in the connecting region between daughter cells could be sometimes recognized. After methanol fixation, no 3-HOKA signal was conserved within cells. The occurrence of a diffuse blue emission induced by 3HOKA in the cytoplasm of living cells did not allow the precise recognition of lysosome-like granules and mitochondrial autofluorescence. In this context, it is also noteworthy that under UV excitation, the well-known blue nuclear emission of DAPI- and Hoechst 33342-labeled live cells also hindered the visualization of NADH-dependent mitochondrial autofluorescence [27,34].

Fluorescent vital probes are now increasingly used in microscopic cell and molecular biology studies in the field of biomedical sciences $[1,35]$. Cell organelles and structures such as lysosomes, mitochondria, Golgi apparatus, endoplasmic reticulum, plasma membrane, chromatin, nucleoli, lipid droplets, etc., are currently visualized in live cells using fluorescent probes belonging to different heterocyclic derivatives (i.e., coumarin, acridine, azine, xanthene, oxazine, carbocyanine, BODIPY, etc.) [35]. Therefore, the fluorescence of 3-HOKA was considered adequate to search for some possible localization within live cells. A bright blue emission in the structure named singular body was clearly visualized after $18 \mathrm{~h}$ treatment with 3-HOKA. Although morphological criteria are valuable to identify unambiguously cell structures, in the present case this assignment was a difficult task. It is worth to note the singular character of this body, which is in contrast with the occurrence of multiple cytoplasmic organelles such as lysosomes, mitochondria, peroxisomes, Golgi dictyosomes, lipid droplets, etc. As formaldehyde or methanol fixation prevents the 3-HOKA fluorescence, additional immunocytochemical methods to identify the singular body could be not applied.

The significance of this intriguing cell component is unknown and deserves further investigation, but it is tempting to speculate that because morphological features such as the number, position, size and shape, this peculiar structure could represent the pair of centrioles $(\sim 0.7 \mu \mathrm{m}$ in length and $\sim 0.2 \mu \mathrm{m}$ in width). Some occasional images
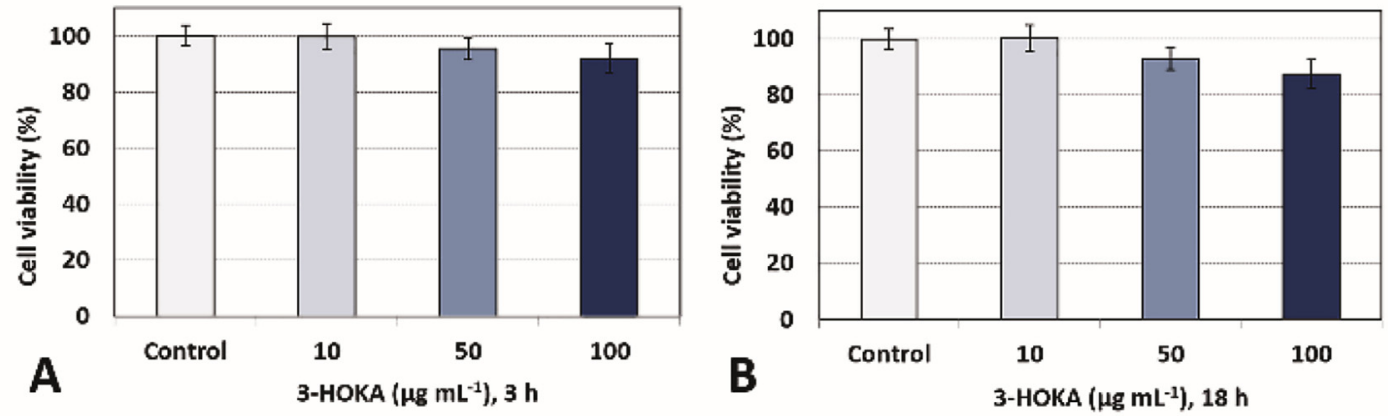

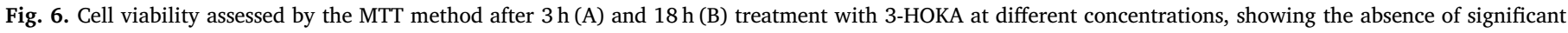
cytotoxic effects. 


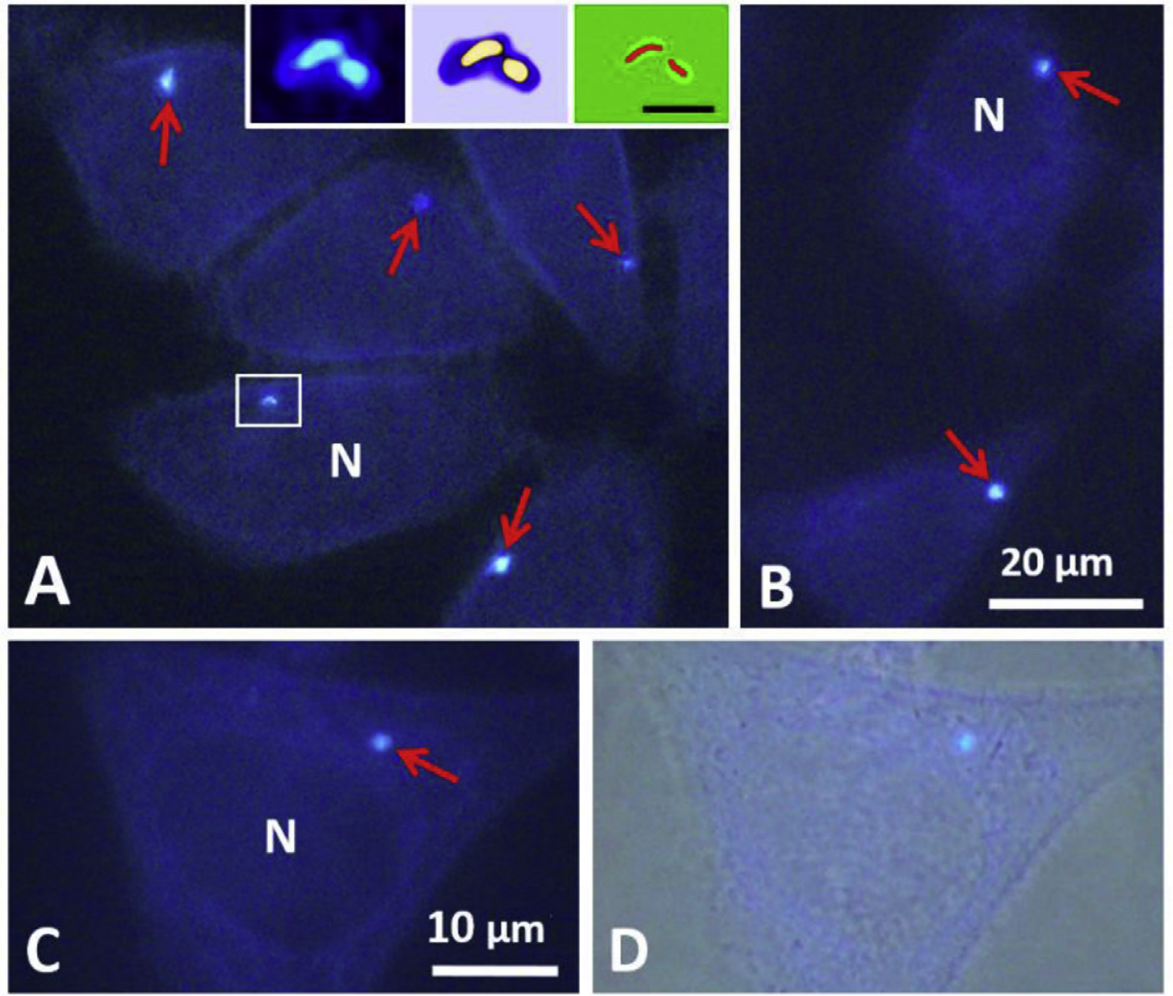

Fig. 7. Fluorescence images of cells treated for $18 \mathrm{~h}$ with $50 \mu \mathrm{g} \mathrm{mL}^{-1}(\mathrm{~A})$, and $10 \mu \mathrm{g} \mathrm{mL}^{-1}$ of 3 -HOKA (B-C) showing the singular body in the cytoplasm (arrows). The picture D corresponds to picture C merged with a phase contrast image. The insert shows the body inside the rectangle in $\mathrm{A}$ at higher magnification (left), after image processing and analysis (IPA) (removed background, LUT: ICA, middle), and as binary IPA image with a merged skeletonized derivative (red axis, right; scale bar: $1 \mu \mathrm{m}$ ). (For interpretation of the references to colour in this figure legend, the reader is referred to the Web version of this article.) showed an almost orthogonal configuration of 2 bars (Fig. 7A, inserts), which strongly suggests the typical geometry of the centriolar pair. Fluorescence fading, inadequate position, and/or out of focus images would result in a bad or no visualization of this body in some cells. Round halos or large granules could also correspond to the centrosome, which is formed by amorphous pericentriolar materials, and behaves as the microtubule-organizing center. Centrosomes have been visualized as round bodies by using antibodies to centrosomal proteins and immunofluorescence microscopy [36].

However, no reports have been found regarding the simple and direct fluorescent visualization of centrioles or centrosomes by small molecular vital probes. It is noteworthy that some morphological features of the centriole, such as its perinuclear position or location near the plasma membrane are shared by the singular body, which could suggest a correspondence between the two structures. Centrioles can move from sites near the nuclear envelope to the cell surface forming the basal bodies of cilia and flagella [37]. Interestingly, during the meiotic division in fruit fly spermatocytes, the distal part of the centriole is first surrounded by a membranous sheath and then protrudes from the cell surface covered by the plasma membrane to form the sperm flagellum [38]. Regarding 3-HOKA, our observations could be related with some effects of tryptophan metabolites along the kynurenine pathway. The treatment of cultured neurons with quinolinic acid, a compound generated from kynurenic acid, induced microtubular
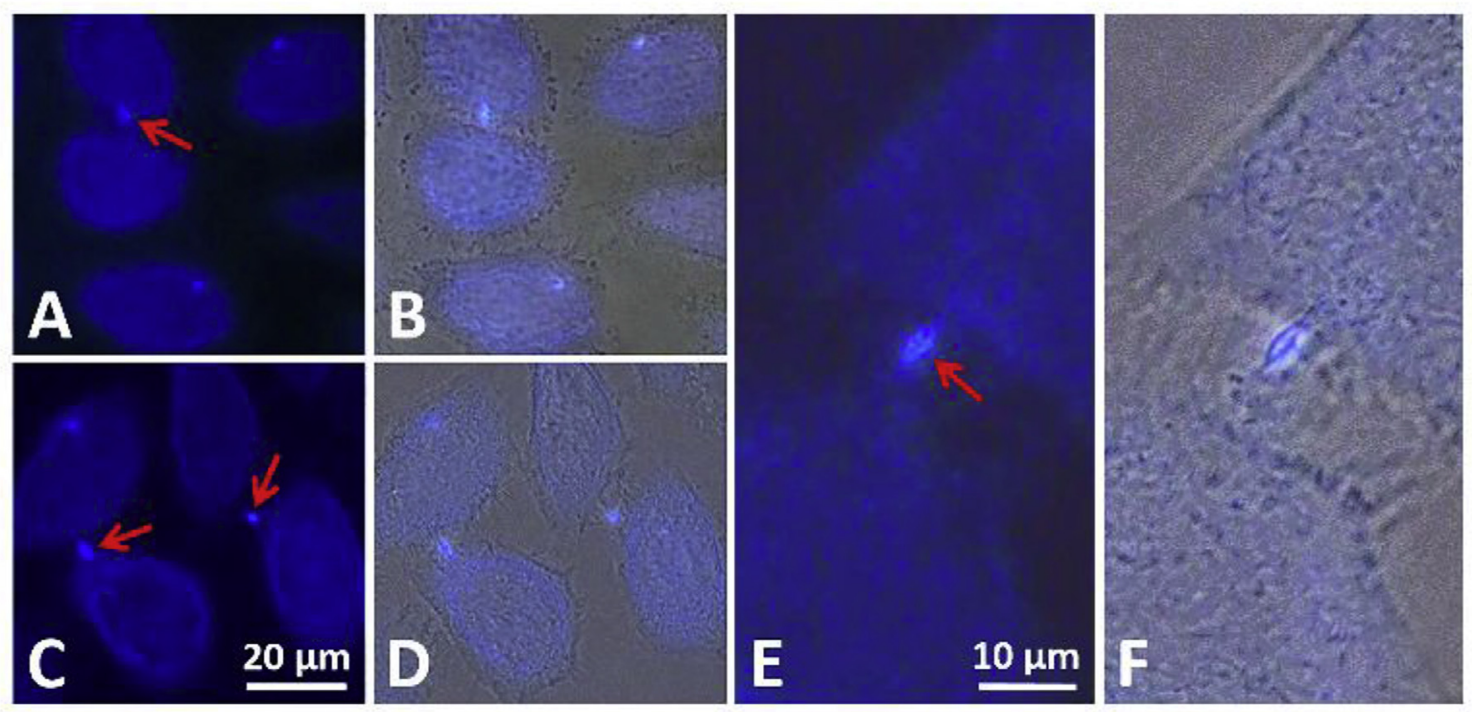

Fig. 8. Fluorescence images of early daughter cells after treatment with 3-HOKA ( $50 \mu \mathrm{gL}^{-1}$ for $18 \mathrm{~h}$ ), showing the singular body in the connecting bridge (A, C, E, arrows), and in the merged images with cells under phase contrast (B, D. F), respectively. 
damage [39]. Kynurenic acid also interferes with the organization and maintenance of the cytoskeletal intermediate filaments [40]. However, in our case no microtubules or other cytoskeleton components were labeled after 3-HOKA treatment, which indicates that this compound has different binding properties and effects compared with those tryptophan derivatives. Further investigations to identify precisely the cell structure labeled by 3-HOKA fluorescence are in course.

\section{Conclusion}

The 3-HOKA could be a new probe for the labeling of centrioles, with special application to the study of flagellated microorganisms, especially taking into account the null cytotoxicity of the compound. Therefore, this novel fluorophore represents a promising prototype compound owing to its biocompatibility and potential biological applications.

\section{Acknowledgements}

This work was financially supported by the Universidad de Buenos Aires, Argentina, UBACyT 2017-2019 N ${ }^{\circ} 20020160100062 B A$, and the Ministerio de Economía y Competitividad, grant №: CTQ2016-7854C2-2-R, España.

\section{Appendix A. Supplementary data}

Supplementary data to this article can be found online at https:// doi.org/10.1016/j.dyepig.2018.10.027.

\section{References}

[1] (a) Zhu H, Fan J, Du J, Peng X. Fluorescent probes for sensing and imaging within specific cellular organelles. Acc Chem Res 2016;49(10):2115-26https://doi.org/10. 1021/acs.accounts.6b00292;

(b) Schäferling M. The art of fluorescence imaging with chemical sensors. Angew Chem Int Ed 2012;51(15):3532-54https://doi.org/10.1002/anie.201105459; (c) Drummen GPC. Fluorescent probes and fluorescence (microscopy) techniques illuminating biological and biomedical research. Molecules

2012;17(12):14067-90https://doi.org/10.3390/molecules171214067;

(d) Kim T, Park J, Park S, Choi Y, Kim Y. Visualization of tyrosinase activity in melanoma cells by a BODIPY-based fluorescent probe. Chem Commun 2011;47:12640-2https://doi.org./10.1039/C1CC15061H.

[2] (a) Sheng RL, Wang PF, Gao YH, Wu Y, Liu WM, Ma JJ, Li HP, Wu SK. Colorimetric test kit for $\mathrm{Cu}^{2+}$ detection. Org Lett 2008;10(21):5015-8https://doi.org/10.1021/ ol802117p;

(b) Jung HS, Kwon PS, Lee JW, Kim JI, Hong CS, Kim JW, Yan SH, Lee JY, Lee JH, Joo T, Kim JS. Coumarin-derived $\mathrm{Cu}^{2+}$-selective fluorescence sensor: synthesis, mechanisms, and applications in living cells. J Am Chem Soc 2009;131(5):2008-12https://doi.org/10.1021/ja808611d.

[3] (a) Wu CY, Wei JJ, Tian DH, Feng Y, Miller RH, Wang YM. Molecular probes for imaging myelinated white matter in CNS. J Med Chem 2008;51(21):6682-8https:// doi.org/10.1021/jm8003637;

(b) Wang CN, Wu CY, Zhu JQ, Miller RH, Wang YM. Design, synthesis, and evaluation of coumarin-based molecular probes for imaging of myelination. $\mathrm{J}$ Med Chem 2011;54(7):2331-40https://doi.org/10.1021/jm101489w.

[4] (a) Kantevari S, Matsuzaki M, Kanemoto Y, Kasai H, Ellis-Davies GCR. Two-color, two-photon uncaging of glutamate and GABA. Nat Methods 2010;7:123-5https:// doi.org/10.1038/nmeth.1413;

(b) Gordo J, Avo J, Parola AJ, Lima JC, Pereira A, Branco PS. Convenient synthesis of 3-vinyl and 3-styryl coumarins. Org Lett 2011;13(19):5112-5https://doi.org/10. 1021/ol201983u;

(c) Jones G, Jackson WR, Choi C, Bergmark WR. Solvent effects on emission yield and lifetime for coumarin laser dyes. Requirements for a rotatory decay mechanism. J Phys Chem 1985;89(2). 294-00 https://doi.org/10.1021/j100248a024; (d) Koefod RS, Mann KR. Preparation, photochemistry, and electronic structures of coumarin laser dye complexes of cyclopentadienylruthenium(II). Inorg Chem 1989;28(12):2285-90https://doi.org/10.1021/ic00311a009.

[5] (a) Textor J, Peixoto A, Henrickson SE, Sinn M, von Andrian UH, Westermann J. Defining the quantitative limits of intravital two-photon lymphocyte tracking. Proc Natl Acad Sci USA 2011;108(30):12401-6https://doi.org/10.1073/pnas. 1102288108;

(b) McDole K, Xiong Y, Iglesias PA, Zheng ZX. Lineage mapping the pre-implantation mouse embryo by two-photon microscopy, new insights into the segregation of cell fates. Dev Biol 2011;355(2):239-49https://doi.org/10.1016/j.ydbio. 2011.04.024;

(c) Gontijo TB, de Freitas RP, de Lima GF, de Rezende LCD, Pedrosa LF, Silva TL,
Goulart MOF, Cavalcanti BC, Pessoa C, Bruno MP, Correia JR, Emery FS, da Silva Júnior EN. Novel fluorescent lapachone-based BODIPY: synthesis, computational and electrochemical aspects, and subcellular localisation of a potent antitumour hybrid quinone. Chem Commun 2016;52(90):13281-4https://doi.org/10.1039/ C6CC07054J.

[6] Laras Y, Hugues V, Chandrasekaran Y, Blanchard-Desce M, Acher FC, Pietrancosta $\mathrm{N}$. Synthesis of quinoline dicarboxylic esters as biocompatible fluorescent tags. J Org Chem 2012;77(18). 8294-02 https://doi.org/10.1021/jo301652j.

[7] (a) Jones RA, McAteer CH, Balasubramanian M, Murugan R. first ed.Katritzky AR, Ramsden CA, Scriven EF, Taylor RJ, editors. Comprehensive heterocyclic chemistry III, vol. 7. Oxford: Elsevier; 2008. p. 309;

(b) Eicher T, Hauptmann S, Speicher A. In the chemistry of heterocycles. second ed. Weinheim: Wiley-VCH; 2003. 6, 316.

[8] Jones RA, Panda SS, Hall CD. Quinine conjugates and quinine analogues as potential antimalarial agents. Eur J Med Chem 2015;97:335-55https://doi.org/10.1016/j. ejmech.2015.02.002.

[9] Afzal A, Kumar S, Haider MR, Ali MR, Kumar R, Jaggi M, Bawa S. A review on anticancer potential of bioactive heterocycle quinoline. Eur J Med Chem 2015;97:871-910https://doi.org/10.1016/j.ejmech.2014.07.044.

[10] (a) Kumar V, Gohain M, Van Tonder JH, Ponra S, Bezuindenhoudt BC Ntwaeaborwa OM, Swart HC. Synthesis of quinoline based heterocyclic compounds for blue lighting application. Opt Mater 2015;50:275-81https://doi.org/10.1016/j. optmat.2015.11.009;

(b) Ejuh GW, Samuel N, Fridolin TN, Ndjaka JM. Computational determination of the electronic and nonlinear optical properties of the molecules 2-(4-aminophenyl) quinoline, 4-(4-aminophenyl) quinoline, anthracene, anthraquinone and phenanthrene. Mater Lett 2016;178:221-6https://doi.org/10.1016/j.matlet.2016.04.097; (c) Ren BY, Zhong D-Z, Sun Y-G, Zhao X-H, Zhang Q-J, Liu Y, Jurow M, Sun M-L, Zhang Z-S, Zhao Y. Quinolyl functionalized spiro[fluorene-9,9'-xanthene] host materials with bipolar characteristics for green and red phosphorescent organic light-emitting diodes. Org Electron 2016;36:140-7https://doi.org/10.1016/j.orgel. 2016.06.006;

(d) Driscoll EW, Hunt JR, Dawlaty JM. Photobasicity in quinolines: origin and tunability via the substituents' hammett parameters. J Phys Chem Lett 2016;7(11):2093-9https://doi.org/10.1021/acs.jpclett.6b00790; (e) Mao M, Zhang X, Zhu B, Wang J, Wu G, Yin Y, Song Q. Comparative studies of organic dyes with a quinazoline or quinoline chromophore as $\pi$-conjugated bridge for dye-sensitized solar cells. Dyes Pigments 2016;124:72-81https://doi.org/10. 1016/j.dyepig.2015.09.002;

(f) Chen C-H, Hsu L-C, Rajamalli P, Chang Y-W, Wu F-I, Liao C-Y, Chiu M-J, Chou P-Y, Huang M-J, Chu L-K, Cheng C-H. Highly efficient orange and deep-red organic light emitting diodes with long operational lifetimes using carbazole-quinoline based bipolar host materials. J Mater Chem C 2014;2(30):6183-91https://doi.org/ 10.1039/C4TC00523F;

(g) Rode ND, Arcadi A, Chiarini M, Marinelli F. An improved environmentally friendly approach to 4-nitro-, 4-sulfonyl-, and 4-aminoquinolines and 4-quinolones through conjugate addition of nucleophiles to $\beta$-(2-Aminophenyl)- $\alpha, \beta$-ynones. Synthesis 2017;49(11):2501-12https://doi.org/10.1055/s-0036-1588147.

[11] Soural M, Hradil P, Křupková S, Hlaváč J. An interesting synthetic pathway to some quinolin-4(1H)ones: phenacylanthranilates rearrangement - limits and scopes. Mini-Reviews Org Chem 2012;9(4):426-32https://doi.org/10.2174/ 157019312804699483.

[12] Motyka K, Hlaváč J, Soural M, Funk P. Fluorescence properties of 2-aryl-3-hydroxyquinolin-4(1H)-one-carboxamides. Tetrahedron Lett 2010;51(38):5060-3https:/ doi.org/10.1016/j.tetlet.2010.07.103.

[13] Putokhin NI. Action of sodium methylate on ethyl isatin-N-acetate. J. Gen. Chim. 1935;5:1176-84. Chem. Abstr. 1935,30:1055.

[14] (a) Blanco MM, Shmidt MS, Schapira CB, Perillo IA. A convenient method for the preparation of 4-Hydroxy-2-methyl-1-oxo-1,2-dihydroisoquinoline-3-carboxylic acid derivatives. Synthesis 2006(12):1971-4https://doi.org/10.1055/s-2006942402;

(b) Blanco MM, Dal Maso M, Shmidt MS, Perillo IA. Reaction of isatin-1-acetamides with alkoxides: synthesis of novel 1,4-Dihydro-3-hydroxy-4-oxo-2-quinolinecarboxamides. Synthesis 2007(6):829-34https://doi.org/10.1055/s-2007965949;

(c) Shmidt MS, Perillo IA, Camelli A, Fernández MA, Blanco MM. Polyfunctional 4 quinolinones. Synthesis of 2-substituted 3-hydroxy-4-oxo-1,4-dihydroquinolines. Tetrahedron Lett 2016;57(9):1022-6https://doi.org/10.1016/j.tetlet.2016.01.077.

[15] Van Rossum B-J, Förster H, de Groot, HJM. High-field and high-speed CP-MAS ${ }^{13} \mathrm{C}$ NMR heteronuclear dipolar-correlation spectroscopy of solids with frequencyswitched Lee-Goldburg homonuclear decoupling. J Magn Reson 1997;124(2):516-9https://doi.org/10.1006/jmre.1996.1089.

[16] (a) Crespi AF, Byrne AJ, Vega D, Chattah AK, Monti GA, Lázaro-Martínez JM Generation and stability of the gem-diol forms in imidazole derivatives containing carbonyl groups. Solid-state NMR and single-crystal X-ray diffraction studies. J Phys Chem A 2018;122(2):601-9https://doi.org/10.1021/acs.jpca.7b12390; (b) Lázaro Martínez JM, Romasanta PN, Chattah AK, Buldain GY. NMR characterization of hydrate and aldehyde forms of imidazole-2-carboxaldehyde and derivatives. J Org Chem 2010;75(10):3208-13https://doi.org/10.1021/jo902588s.

[17] Zhang XF, Li X. The photostability and fluorescence properties of diphenylisobenzofuran. J Lumin 2011;131(11):2263-6https://doi.org/10.1016/j.jlumin.2011. 05.048 .

[18] (a) Lagorio MG, Dicelio LE, San Román E. Visible and near-IR spectroscopic and photochemical characterization of substituted metallophthalocyanines. J Photochem Photobiol Chem 1993;72(2):153-61https://doi.org/10.1016/1010 6030(93)85022-Z; 
(b) Kraljić I, El Mohsni S. A new method for the detection of singlet oxygen in aqueous solutions. Photochem Photobiol 1978;28(4-5):577-81https://doi.org/10. 1111/j.1751-1097.1978.tb06972.x.

[19] Lee PCC, Rodgers MAJ. Laser photokinetic studies of rose bengal sensitized photodynamic interactions of nucleotides and DNA. Photochem Photobiol 1987;45(1):79-86https://doi.org/10.1111/j.1751-1097.1987.tb08407.x.

[20] Amore S, Lagorio MG, Dicelio LE, San Román E. Photophysical properties of supported dyes. Quantum yield calculations in scattering media. Prog React Kinet Mech 2001;26(2-3):159-77https://doi.org/10.3184/007967401103165235.

[21] Schnurpfeil G, Sobbi AK, Spillger W, Kliesch H, Wöhrle DJ. Photo-oxidative stability and its correlation with semi-empirical MO calculations of various tetraazaporphyrin derivatives in solution. J Porphyr Phthalocyanines 1997;1(2):159-67. < 159::AID-JPP19 > 3.0.CO;2-8 https://doi.org/10.1002/ (SICI)1099-1409(199704)1:2.

[22] (a) Behrman EJ. The Elbs and Boyland-Sims peroxydisulfate oxidations. Beilstein J Org Chem 2006;2(22):1-10https://doi.org/10.1186/1860-5397-2-22;

(b) Behrman EJ, Kiser RL, Garas WF, Behrman EC, Pitt BM. Conversion of 4-quinolones into 3-hydroxy-4-quinolones via the corresponding sulfates. J Chem Res 1995(5):164-5. NII Article ID (NAID)10030637842.

[23] Ainley AD, Robinson R. The epindoline group. Part I. Trial of various methods for the synthesis of epindolidiones. J Chem Soc 1934(0):1508-20https://doi.org/10. 1039/JR9340001508.

[24] Coppini D. Derivati 3-4-diossichinolinici. Gazz Chim Ital 1950;80:36-41.

[25] Surrey AR, CutlerRA. The preparation of 3-Halo-4-dialkylaminoalkylaminoquinoline derivatives. J Am Chem Soc 1946;68(12):2570-4https://doi.org/10.1021/ ja01216a044.

[26] Juarranz A, Espada J, Stockert JC, Villanueva A, Polo S, Dominguez V, Cañete M. Photodamage induced by zinc(II)-phthalocyanine to microtubules, actin, $\alpha$-actinin and keratin of HeLa cells. Photochem Photobiol 2001;73(3):283-9https://doi.org/ 10.1562/0031-8655(2001)0730283PIBZIP2.0.CO2.

[27] Cañete M, Juarranz A, López-Nieva P, Alonso-Torcal C, Villanueva A, Stockert JC. Fixation and permanent mounting of fluorescent probes after vital labelling of cultured cells. Acta Histochem 2001;103(3):117-26https://doi.org/10.1078/00651281-00594.

[28] (a) Mosmann T. Rapid colorimetric assay for cellular growth and survival: application to proliferation and cytotoxicity assays. J Immunol Methods 1983;65(1-2):55-63. PMID:6606682;

(b) Stockert JC, Blázquez-Castro A, Cañete M, Horobin RW, Villanueva A. MTT assay for cell viability: intracellular localization of the formazan product is in lipid droplets. Acta Histochem 2012;114(8):785-96https://doi.org/10.1016/j.acthis. 2012.01.006.

[29] (a) Crespi AF, Vega D, Chattah AK, Monti GA, Buldain GY, Lázaro-Martínez JM. gem-Diol and hemiacetal forms in formylpyridine and vitamin- $\mathrm{B}_{6}$-related compounds: solid-state NMR and single-crystal X-ray diffraction studies. J Phys Chem A 2016;120(39):7778-85https://doi.org/10.1021/acs.jpca.6b07898; (b) Garro Linck Y, Chattah AK, Graf R, Romañuk CB, Olivera ME, Manzo RH, Monti GA, Spiess HW. Multinuclear solid state NMR investigation of two polymorphic forms of Ciprofloxacin-saccharinate. Phys Chem Chem Phys 2011;13:6590-6https://doi.org/10.1039/COCP02919J.

[30] Sherin PS, Gritsan NP, Tsentalovich YP. Experimental and quantum chemical study of photochemical properties of 4-hydroxyquinoline. Photochem Photobiol Sci 2009;8:1550-7https://doi.org/10.1039/B9PP00017H.

[31] Pileni MP, Giraud M, Santus R. Kynurenic acid - II. Photosensitizing properties. Photochem Photobiol 1979;30(2):257-61https://doi.org/10.1111/j.1751-1097. 1979.tb07144.x.

[32] Samanta A, Guchhait N, Bhattacharya SC. Photophysical aspects of biological photosensitizer. Kynurenic acid from the perspective of experimental and quantum chemical study. Spectrochim Acta Mol Biomol Spectrosc 2014;129:457-65https:// doi.org/10.1016/j.saa.2014.03.079.

[33] Alberts B, Bray D, Lewis J, Raff M, Roberts K, Watson JD. Molecular biology of the cell. second ed. New York, London: Garland Publishing, Inc.; 1989. 650, 652, 781.

[34] Grossgebauer K. Staining of phagocytized Cryptococcus neoformans with DAPI. Microsc Acta 1983;87(3):307-10. PMID: 6195510.

[35] (a) Horobin RW, Kiernan JA. Conn's biological stains. A handbook of dyes, stains and fluorochromes for use in biology and medicine. tenth ed. Oxford, UK: BIOS Scientific Publishers; 2002;

(b) Stockert JC, Blázquez-Castro A. Fluorescence microscopy in life sciences. Sharjah, U.A.E.: E-Book, Bentham Science Publishers; 2017. p. 481-531https://doi. org $/ 10.2174 / 97816810851801170101$

(c) Horobin RW, Stockert JC. Uptake and localization mechanisms of fluorescent and colored lipid probes. 1. Physicochemistry of probe uptake and localization, and the use of QSAR models for selectivity prediction. Biotech Histochem 2011;86:379-93https://doi.org/10.3109/10520295.2010.515489;

(d) Horobin RW, Stockert JC, Rashid-Doubell F. Uptake and localisation of smallmolecule fluorescent probes in living cells: a critical appraisal of QSAR models and a case study concerning probes for DNA and RNA. Histochem Cell Biol 2013;139(5):623-37https://doi.org/10.1007/s00418-013-1090-0;

(e) Horobin RW, Stockert JC, Rashid-Doubell F. Uptake and localization mechanisms of fluorescent and colored lipid probes. Part 2. QSAR models predicting localization of fluorescent probes used to identify ("specifically stain") various biomembranes and membranous organelles. Biotech Histochem

2015;90(4):241-54https://doi.org/10.3109/10520295.2015.1005129;

(f) Durán-Sampedro G, Epelde-Elezcano N, Martínez-Martínez V, Esnal I, Bañuelos J, García-Moreno I, Agarrabeitia AR, de la Moya S, Tabero A, Lazaro-Carrillo A, Villanueva A, Ortiz MJ, López-Arbeloa I. A versatile fluorescent molecular probe endowed with singlet oxygen generation under white-light photosensitization. Dyes Pigments 2017;142:77-87https://doi.org/10.1016/j.dyepig.2017.03.026.

[36] Brenner SL, Brinkley BR. Tubulin assembly sites and the organization of microtubule arrays in mammalian cells. Cold Spring Harbor Symp Quant Biol 1982;46:241-53https://doi.org/10.1101/SQB.1982.046.01.02.

[37] Fulton C. Centrioles. In: Reinert J, Ursprung H, editors. Origin and continuity of cell organelles. Berlin: Springer-Verlag; 1971. p. 170-5.

[38] Tates AD. Pasmans DJH, 'S-Gravenhageeditors. Cytodifferentiation during spermatogenesis in Drosophila melanogaster. Netherlands Leiden, Netherlands: Ph.D. Thesis, Department of Radiation Genetics, University of Leiden; 1971.

[39] Stone TW. Kynurenines in the CNS: from endogenous obscurity to therapeutic importance. Prog Neurobiol 2001;64(2):185-218. PMID:11240212.

[40] Pierozan P, Pessoa-Pureur R. Cytoskeleton as a target of quinolinic acid neurotoxicity: insight from animal models. Mol Neurobiol 2018;55(5):4362-72https:// doi.org/10.1007/s12035-017-0654-8. 